\title{
Larval Development, Larval Nutrition and Growth for Two Boccardia Species (Polychaeta: Spionidae) from Victoria, Australia
}

\author{
James A. Blake ${ }^{1}$ and Jerry D. Kudenov ${ }^{2}$ \\ 1 Battelle's New England Marine Research Laboratory, P. O. Drawer AH, Duxbury, Massachusetts 02332, USA \\ and \\ Department of Biology, Suffolk University, Beacon Hill, Boston, Massachusetts 02114, USA \\ 2 Department of Biological Sciences, University of Alaska, Anchorage, Alaska 99504, USA
}

\begin{abstract}
Larvae of Boccardia proboscidea and B. chilensis were reared in laboratory culture from egg capsules deposited by adults into tubes. B. proboscidea exhibıts an unusual form of adelphophagia where 2 forms of larvae co-occur within the egg capsules: small forms incapable of feeding on nurse eggs and larger, more precocious larvae which feed on nurse eggs and smaller larval forms. The small larval forms are believed to be capable of a long pelagic life if they survive cannibalism by larger larvae; the large larvae have only a short pelagic life or none at all. Th.s plasticity in mode of larval development should make it possible for $B$. proboscidea to disperse its larvae to distant localities, at the same time building up local populations. The larval development of $B$. chilensis is described from egg through large planktonic stages. Nurse eggs are lacking and larvae become planktonic at the 4 -setiger stage. They apparently have a long pelagic life; metamorphosis was not induced in the laboratory. $B$. chilensis larvae are unusual among the species of Boccardia in lacking a dorsal medial row of chromatophores. There are minor differences between Australian B. chilensis larvae and published records of Chilean larvae. The biology of those spionid polychaete speries exhibiting differences in reproductive patterns is reviewed and compared with $B$. proboscidea.
\end{abstract}

\section{INTRODUCTION}

Boccardia proboscidea Hartman is well known from North Pacific localities (Hartman, 1941; 1969; Imajima and Hartman, 1964) and was recently reported from Port Phillip Bay, Victoria, Australia (Blake and Kudenov, 1978). The species was probably introduced to Port Phillip Bay, as it is not known elsewhere in Australia or from any other locality in the southern hemisphere.

Boccardia chilensis Blake and Woodwick is a widespread southern hemispheric species and is known from intertidal and subtidal habitats in Chile (Blake and Woodwick, 1971), New Zealand (Rainer, 1973: as B. jubata; Read, 1975) and Australia (Blake and Kudenov, 1978).

Boccardia proboscidea was the subject of several larval investigations in California (Hartman, 1941; King, 1976; Woodwick, 1977) and has been determined to be an opportunistic species in intertidal benthic communities (Johnson, 1970). The biology of B. chilen- sis, however, is poorly known, with only fragmentary observations available on its egg capsules (Read, 1975) and pelagic larvae (Carrasco, 1976). The present study provides observations on the reproduction and larval development of the 2 species in Australia. The nature and extent of poecilogony and adelphophagia in Boccardia species and other spionids is reviewed following the new observations on $B$. proboscidea.

\section{MATERIAL AND METHODS}

Tubes containing adults of Boccardia proboscidea and $B$. chilensis were collected by hand from wellsorted, silty sediments accumulated between and under basalt rocks surrounding the $145 \mathrm{~W}$ Drain of the Werribee Sewage Treatment Farm in Port Phillip Bay on 21 February and 3 March, 1977.

In the laboratory, the tubes were carefully opened and adults and egg capsules removed. The egg capsules were placed in Petri dishes containing filtered 
seawater $\left(33-34 \% \mathrm{~S} ; 20^{\circ}-21^{\circ} \mathrm{C}\right)$. Observations on larval growth rates and extrinsic feeding on nurse eggs and embryos were conducted on encapsulated Boccardia proboscidea larvae over a 48 -h period. Larvae were staged by counting the dorsal chromatophores. Each developing larva bears a single dorsal chromatophore until the 4 -setiger stage when a second is added. Each subsequent segment to be added is accompanied by a chromatophore making it possible to determine the number of segments on larvae still inside the capsules. This relationship was established by Woodwick (1977). After hatching or decapsulation the larvae were fed a commercial fish food (Tetra Conditioning Food, F. R. Germany), pulverized into a fine powder. A suspension of this powder was prepared in filtered seawater. After agitation, the heavier particles were allowed to settle; a few drops of the lighter suspension were fed to the larvae. Water and food were changed every $2 \mathrm{~d}$. The sequential stages of development were recorded and observations made on larval morphology.

\section{RESULTS}

\section{Boccardia proboscidea Hartman}

Development in the Capsules

Egg capsules of Boccardia proboscidea are translucent, oval-shaped structures; they are individually deposited in a row within each tube. Each capsule is attached to the tube wall by a thin, transparent stalk. Up to 32 capsules were observed in one tube, but 10-13 $(\bar{X}=16)$ per tube is more typical. Up to 130 unfertilized nurse eggs $(\bar{X}=40.86, s= \pm 17.63)$ and from $1-10$ developing larvae occur in a capsule $(\bar{X}=4.5$ per capsule, $\mathrm{N}=63, s= \pm 1.98$ ). Unfertilized eggs are yellow, fertilized eggs orange.

Two types of larvae were found in the capsules. One type (Group I) remained small and never developed more than 8 setigers (usually 4-5) in the capsules, the second type (Group II) grew to a large size (9-16 setigers). Differential growth rates were established for these 2 larval groups. Observations were made on 176 larvae from 32 capsules over a $48 \mathrm{~h}$ period (March 7-9, 1977).

A total of 131 Group I larvae were present initially (March 7, 1977). Most (123) were in the 3-5 setiger. range $(\bar{X}=4.44, s= \pm 0.79)$. Forty-five larvae were classed as Group II and ranged from 9-14 setigers ( $\overline{\mathrm{X}}=$ $10.89, s= \pm 1.03$ ). The size distribution of these 2 groups of larvae is shown in Fig. 1 A. Two days later $(9$ March 1977), the number of Group I larvae was reduced to 62 (size: $\bar{X}=4.87, s= \pm 1.46$ setigers) while the number of Group II larvae remained at 45 , but were considerably larger $(\overline{\mathrm{X}}=14.46, s= \pm 1.20$ setigers) (Fig. 1 B). Group II larvae were observed with setae and other remains of Group I larvae in their guts. One Group II larva was actually observed to engulf a Group I larva. A total of 61 Group I larvae were cannibalized by Group II larvae during the $2 \mathrm{~d}$ interval. A distinct gap at the 9-setiger stage suggests that no

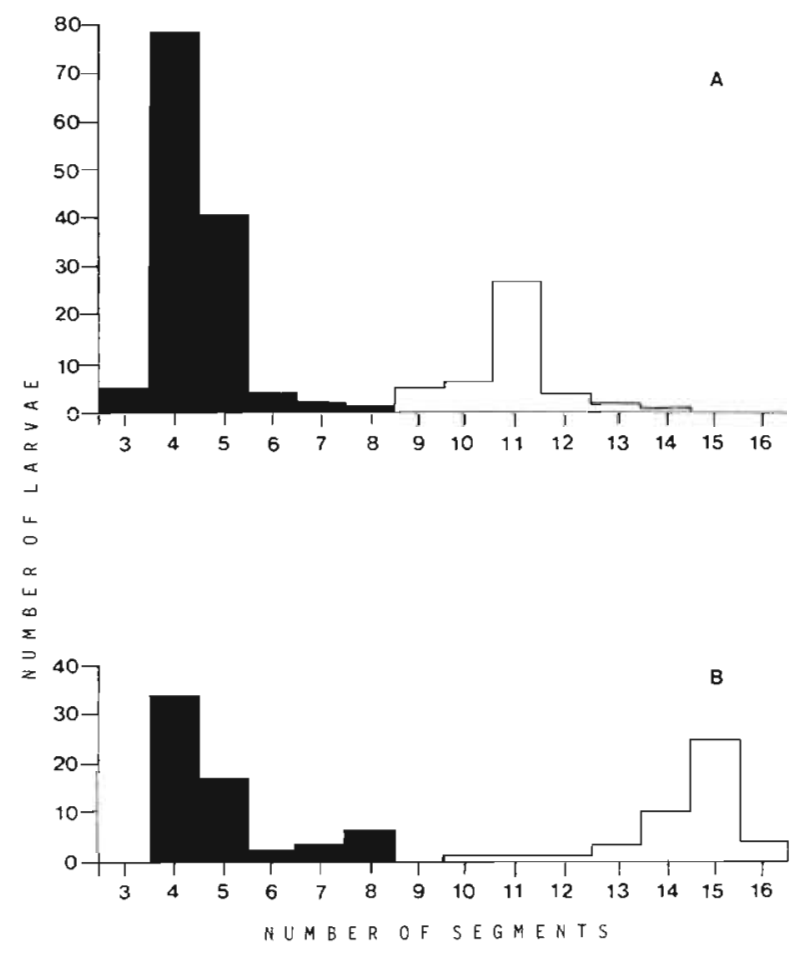

Fig. 1. Boccardia proboscidea. Frequency diagrams of number of larvae versus number of body segments. Distribution of Group I and II larvae: (A) on 7 March 1977; (B) on 9 March 1977. Black columns: Group Ilarvae; white columns: Group II larvae

Group I larva increased beyond the 8-setiger stage. The average number of nurse eggs eaten by a Group II larva was 16.81 for the $2 \mathrm{~d}$ experimental period (Initial number of nurse eggs/capsule: $\bar{X}=40.86, s= \pm$ 17.63; reduced after $2 \mathrm{~d}$ to: $\bar{X}=24.05, s= \pm 24.43$ ). Group I larvae added an average of 0.43 segments after $2 \mathrm{~d}$, while Group II larvae added an average of 2.2 segments for the same period. The growth rates of the 2 groups differ by a factor of 5.45. Both groups exhibited fast initial growth rates, but Group I larvae did not grow significantly during the final phase of observations (Fig. 2). Empty guts indicated that Group I larvae had not eaten the nurse eggs. Group II larvae had full guts, grew rapidly and attained the size for metamorphosis in one week from the time of egg deposition (Fig. 2). Surviving Group I larvae removed from the egg capsules and fed the fish food suspension resumed growth. 


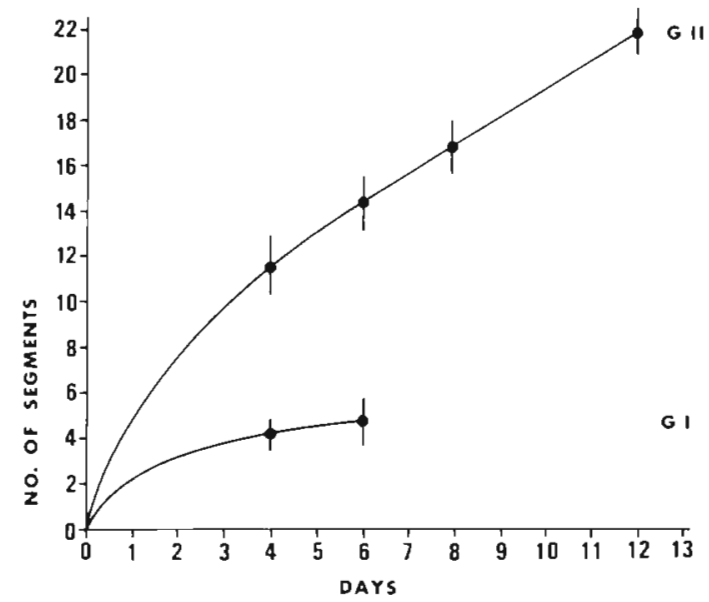

Fig. 2. Boccardia proboscidea. Growth curves for Group I and Group II larvae reared in the laboratory. Black circles: means; vertical bars: $95 \%$ confidence intervals

\section{Emergence from Capsules and Metamorphosis}

Group II Boccardia proboscidea larvae undergo metamorphosis after they have developed $15-16$ setigers. If this growth stage occurs before or at the time they emerge from the capsules, the development is non-pelagic with the juveniles crawling off to build a tube. If, however, they escape from the capsules at an earlier stage, they will spend a variable amount of time in the plankton, where they feed and grow to the appropriate size for metamorphosis. Any Group [ larva escaping from the capsules would have a prolonged pelagic phase.

The fully developed larvae of Boccardia proboscidea are characterized by a large, fusiform-shaped body and an overall faint green coloration. A prominent row of dorsal chromatophores occurs medially from Setiger 3. Lateral black spots are present on Setigers 7, 8 and sometimes 9 . Cilia include the prototroch, telotroch, a short neurotroch, a ciliated pit on Setiger 2, gastrotrochs on Setigers 5 and 7 and nototrochs from Setiger 3. Grasping cilia are lacking. Nuchal cilia occur on either side of the developing caruncle. The prostomium bears many sensory cilia and 3 pairs of black eyes. Adult setae include capillaries, bidentate hooded hooks from Setiger 7 and major spines on Setiger 5. Major spines include both simple and bristle topped forms.

The crawling juveniles form tubes from sand added to the culture dishes, and anchor them to the bottom. Specimens with 21-23 setigers developed branchiae from Setiger 7 , but lacked them on more anterior setigers. Specimens having $27-28$ setigers had branchiae on Setigers $2,3,4,-, 6$ and those following. These anterior branchiae were more conspicuous after the development of 32-34 setigers.

\section{Boccardia chilensis Blake and Woodwick}

Egg capsules were obtained from the tubes of Boccardia chilensis females in February and March in Port
Fig. 3. Boccardia chilensis. (A) Egg capsules; (B) early embryo removed from egg capsule; (C) 3-segment, pre-setiger larva, ventral view; (D) planktonic 4setiger larva, dorsal view; (E) detail of provisional seta from same

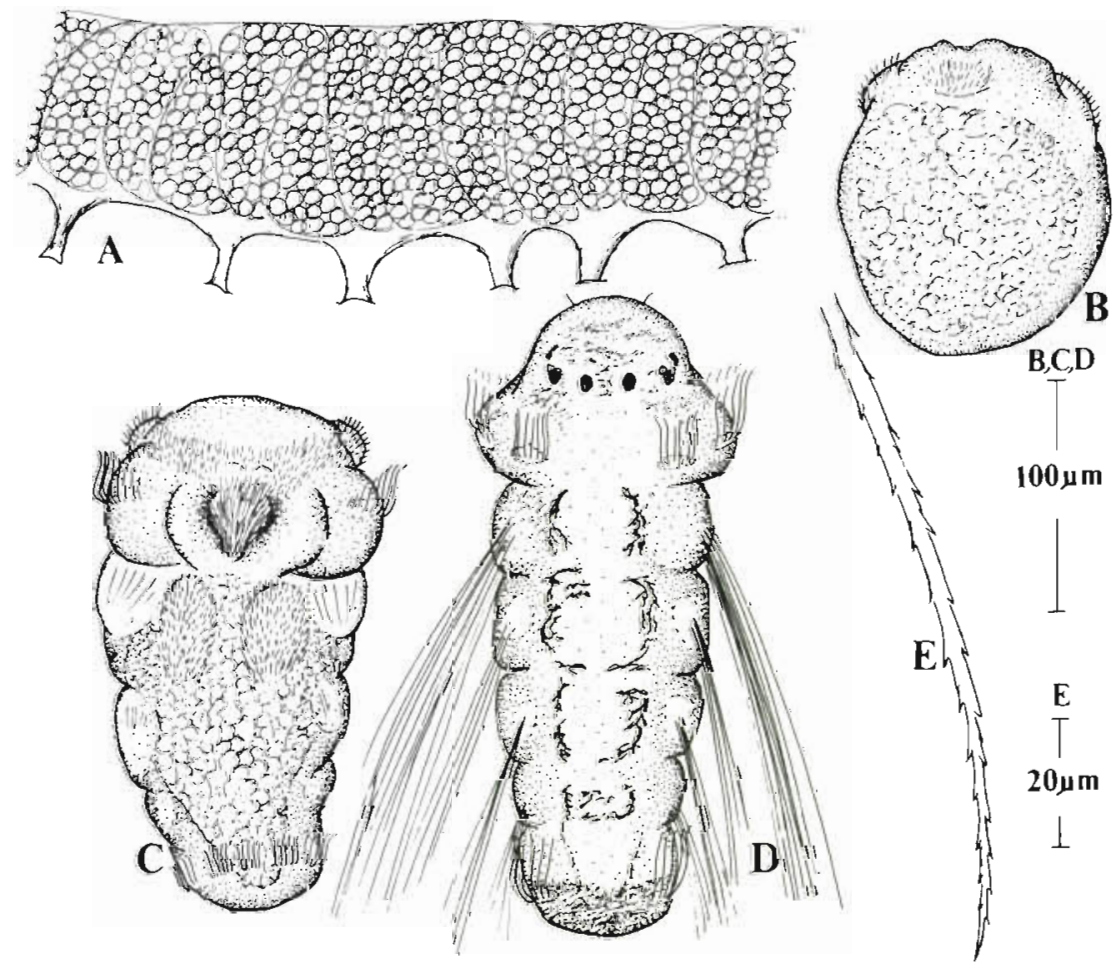


Phillip Bay Each capsule is joined to the next forming a long beadlike chain. For every 2 capsules, there is a single thread of attachment to the tube wall (Fig. 3A), instead of 1 or 2 per capsule as is typical for related species (Blake, 1969). Each chain has an average of 20 capsules. The number of eggs per capsule averages 65 with an average diameter of $120 \mu \mathrm{m}$.

\section{Development in Capsules}

All eggs are fertilized and develop into larvae. The earliest embryo removed from a capsule measures $140 \mu \mathrm{m}$ long and $120 \mu \mathrm{m}$ wide (Fig. 3 B). A small ciliated mouth is developing medial to 2 anterolateral ciliated patches which are the primary prototroch. The rest of the body is undifferentiated.

A 3-segment, asetigerous larvae $230 \mu \mathrm{m}$ long and $130 \mu \mathrm{m}$ wide, is illustrated in (Fig. $3 \mathrm{C}$ ). The body is unpigmented at this stage. There are 2 pairs of eyes. The medial pair is oval in shape, while the lateral pair is irregularly shaped. The mouth has deepened into a $\mathrm{V}$-shaped vestibule with conspicuous lateral lips. The primary prototroch is formed by 2 lateral and 2 dorsal ciliated bulges. A line of short cilia extends from the lateral bulges to merge ventrally with the vestibule. The true or secondary prototroch consists of much longer cilia and is laterally located on the prostomium. The 3 segments are distinct and bear setal sacs containing rudiments of the provisional setae. The telotroch is well-developed and formed of 5-6 patches of cilia. Two ventromedial ciliary patches are present on Setiger 1 .

\section{Development in the Plankton}

The 4 -setiger larvae (Fig 3 D) emerge from the capsules approximately $3 \mathrm{~d}$ after egg deposition. They are approximately $270 \mu \mathrm{m}$ long and $120 \mu \mathrm{m}$ wide. The body is widest at the peristomium from which it gradually tapers posteriorly. The prostomium is rounded on the anterior margin and bears 2 sensory cilia. The peristomium flares laterally, and ventrally forms the lateral lips of the vestibule. A short neurotroch extends posteriorly from the mouth across Setiger 1 . The prototroch consists of several distinct patches of cilia which dorsally leave a wide gap and ventrally merge with the vestibule. Each segment is provided with a setal sac from which serrated provisional setae emerge (Fig. $3 \mathrm{E}$ ), those of Setiger 1 being the longest. The setal sacs produce about 13 such setae in Setiger $1,7-8$ in Setiger 2 and $4-5$ in Setigers 3 and 4 . The telotroch is composed of 5 ciliated patches leaving a wide dorsal gap. Pygidial bacillary glands are located ventrally, just below the telotroch. Light brown pigment occurs dor-

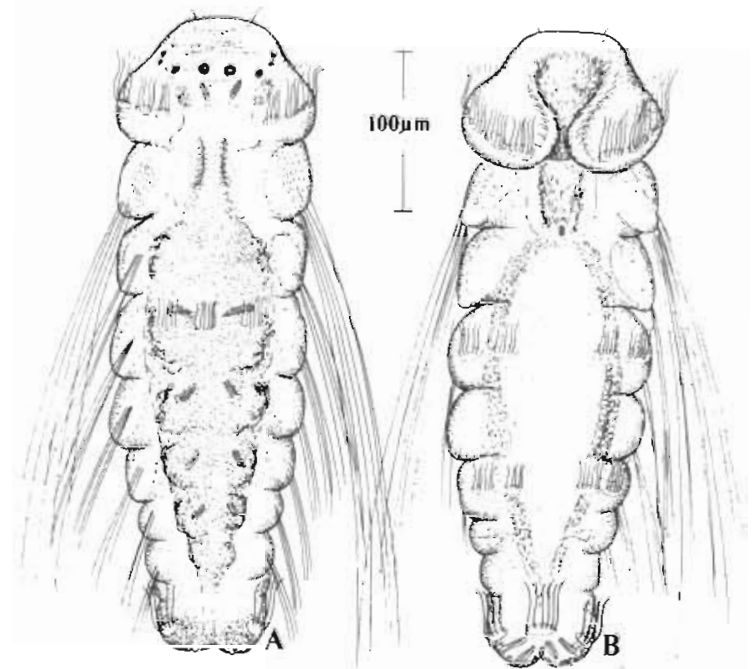

Fig. 4. Boccardia chilensis. (A) Planktonic 7-setiger larva, dorsal view; (B) same larva, ventral view

sally on the prostomium and peristomium. A slightly darker brown area occurs on the pygidal segment and surrounds the patches of the telotroch. Black granular pigment forms an irregular dorsal pattern, but there are no distinct chromatophores. Internally, the walls of the vestibule and lining of the gut are darkly pigmented.

A 9-10 d old 7-setiger larva (Fig. 4 A-B) measures approximately $400 \mu \mathrm{m}$ long and $130 \mu \mathrm{m}$ wide. The prostomium is broad on the anterior margin and bears a few sensory cilia. There are 3 pairs of eyes. A pair of bacillary glands and nuchal organs are located just posterior to the medial pair of eyes. Additional bacil-

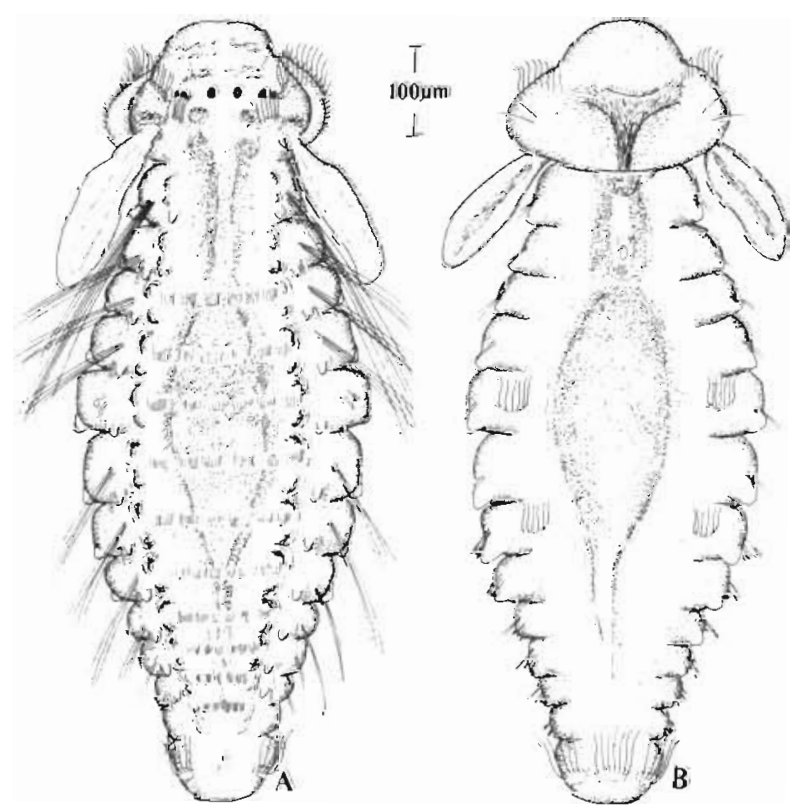

Fig. 5. Boccardia chnensis. (A) Planktonic 12-setiger larva dorsal view; (B) same larva, ventral view 


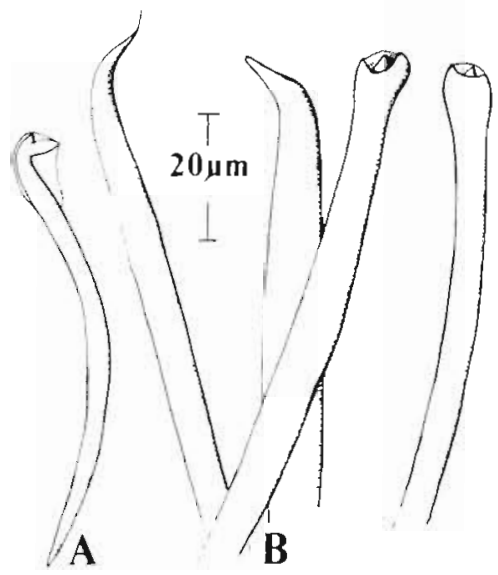

Fig. 6. Boccardia chilensis. (A) Hooded hook from 12-setiger larva; (B) 2 simple and 2 cusped spines from Setiger 5 of a 12 setiger larva

lary glands are located dorsally on Setigers 3-6 and ventrally on the pygidium. The prototroch consists of 6 distinct patches of cilia on either side of the peristomium, leaving a wide dorsal gap. Ventrally, these cilia merge with those of the vestibule. Body segments are relatively uniform in appearance. The provisional setae of Setiger 1 are longest and extend the entire length of the body. Nototrochs are present as 3 distinct patches on Setiger 3. Gastratrochs occur as 4 distinct patches on Setigers 3 and 5. The telotroch is formed of 5 distinct patches with a wide dorsal gap. Light brown pigment is located on the anterior and posterior ends of the larva. Black granular pigment occurs on the dorsal side of each segment. Black pigment internally lines the vestibule and gut walls.

A fully developed 12-setiger larva (Fig. 5 A-C) measures $790 \mu \mathrm{m}$ long and $295 \mu \mathrm{m}$ wide. The individual figured is $30 \mathrm{~d}$ old. The body has assumed a fusiform shape with the widest point being at Setigers 5 and 6 . Internal black pigmentation is conspicuous in the pharynx, gut and proctodeum. The dorsal surface bears

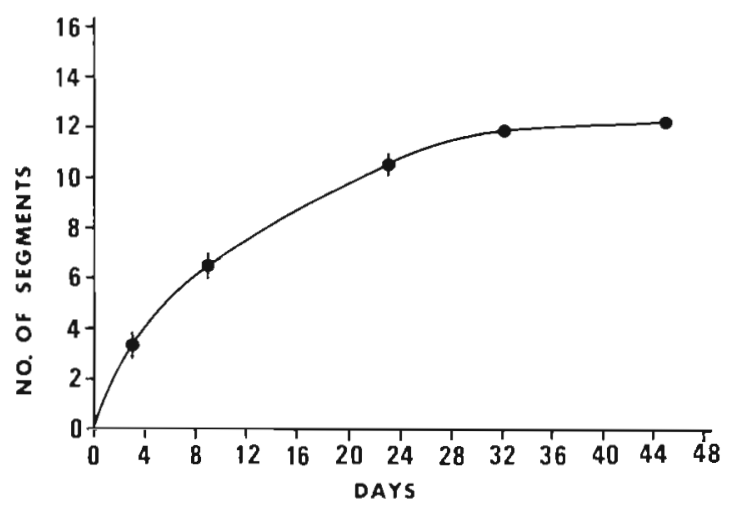

Fig. 7. Boccardia chilensis. Growth curve for laboratory reared larvae. Black circles: means; vertical bars: $95 \%$ confidence intervals a lateral granular pigment on the segmental margins. Brown pigment occurs in variable intensity on the prostomium, pygidium and dorsal surface. The prostomium is broad and vaguely incised on the anterior margin. There are 3 pairs of eyes. A pair of palps arises from the peristomium, with each having a ciliated groove. The prototroch is formed of several distinct patches of cilia which ventrally merge with the vestibule and dorsally are separated by a wide gap. Two patches of nuchal cilia occur just posterior to the medial pair of eyes. Nototrochs are composed of 6 distinct patches of cilia and occur on each segment from Setiger 3. Grasping cilia were not observed. Gastrotrochs occur on Setigers 5 and 7 as single lateral patches; they have been lost on Setiger 3. The neurotroch is reduced to an inconspicuous area of cilia just posterior to the mouth. The ciliated pit is located medially on Setiger 2. The telotroch is well-developed and still composed of 5 separate patches of cilia. Each segment has conical noto- and neuropodia, with those of the neuropodia being largest. Adult setae are developed, although the provisional setae are still present. Three bidentate hooded hooks occur from Setiger 7 (Fig. $6 \mathrm{~A}$ ). There are no accompanying capillary setae. The modified spines of Setiger 5 include 2 falcate and 2 cusped spines (Fig. 6 B)

\section{Growth Rate and Settlement}

Larval growth was slow in culture (Fig. 7). At $20^{\circ}-21^{\circ} \mathrm{C}$ the growth was gradual over a 45 -d period of observation. No larvae grew further than the 12 -setiger stage (Fig. 5 A), and none underwent metamorphosis despite repeated efforts to supply substrata from the adult locality. The fish food diet appeared to be insufficient to promote further growth and development of juveniles during the later pelagic phases.

\section{DISCUSSION}

Certain polychaete species have remarkable abilities to vary their mode of reproduction and developmental pattern throughout their geographic range or from one season of the year to the next (Thorson, 1950). This variability or polymorphism of larval type is called 'poecilogony' (Giard, 1892, 1904): it has been reviewed by Hannerz (1956), Simon (1967, 1968), Blake (1969) and Clark (1977). The best studied examples in the Spionidae are: Pygospio elegans Claparède (Söderström, 1920; Thorson, 1946; Rasmussen, 1953, 1973; Hannerz, 1956); Spio martinensis Mesnil (Hannerz, 1956); Spio setosa Verrill (Simon, 1967, 1968); and Polydora quadrilobata Jacobi (Blake, 
1969). In general, the variability of developmental patterns in the first 3 named species involve the presence of long-lived pelagic larvae during one season of the year and an extended period of brood protection involving nurse egg feeding 'adelphophagia' during another season. Seasonal boundaries, however, are generally not well-documented, and $P$. elegans introduces further complexity by reproducing asexually as well as sexually (Rasmussen, 1953, 1973). Chia (1974) and Woodwick (1977) have treated adelphophagia as a form of lecithotrophic development since the adult simply deposits the yolk in nurse eggs rather than the cytoplasm of the normally developing eggs. This point of view is here accepted.

Rasmussen (1973) considered that developmental differences in Pygospio elegans were due to environmental cues and were not genetically inherent in any one population. It is possible that this is also the case with Spio martinensis and $S$, setosa. The situation with Polydora quadrilobata as described by Blake (1969), however, appears to be different. In a type of larval development where nurse eggs are produced (Type I),

Table 1 Geographic distribution and reproductive habits of the known species of Boccardia

\begin{tabular}{|c|c|c|c|}
\hline Species & Distribution & Larval biology & References \\
\hline acus Rainer & $\begin{array}{l}\text { Southern hemisphere: } \\
\text { New Zealand }\end{array}$ & With or without nurse eggs & Rainer (1973); Read (1975) \\
\hline androgyna Read & $\begin{array}{l}\text { Southern hemisphere: } \\
\text { New Zealand }\end{array}$ & With or without nurse eggs & Read (1975) \\
\hline anophthalma (Rioja) & Northern hemisphere: Mexico & $?$ & Blake (1981) \\
\hline basilaria Hartman & Northern hemisphere: California & ? & Hartman (1961) \\
\hline $\begin{array}{l}\text { berkeleyorum Blake and } \\
\text { Woodwick }\end{array}$ & Northern hemisphere: California & Without nurse eggs & $\begin{array}{l}\text { Blake and Woodwick (1971); } \\
\text { Blake unpubl. }\end{array}$ \\
\hline chilensis Blake and & Southern hemisphere: Australia, & With or without nurse eggs & Blake and Woodwick (1971); \\
\hline Woodwick [= jubata Rainer] & $\begin{array}{l}\text { New Zealand, Chile, Falkland } \\
\text { Islands }\end{array}$ & $\begin{array}{l}\text { (New Zealand); without } \\
\text { nurse eggs (Australia) }\end{array}$ & Read (1975); This study \\
\hline columbiana Berkeley & $\begin{array}{l}\text { Northern hemisphere: California; } \\
\text { British Columbia }\end{array}$ & Without nurse eggs & Woodwick (1963a) \\
\hline knoxi Rainer & $\begin{array}{l}\text { Southern hemisphere: } \\
\text { New Zealand }\end{array}$ & $\begin{array}{l}\text { With nurse eggs, } \\
\text { nonplanktonic larvae }\end{array}$ & Rainer (1973); Read (1975) \\
\hline lamellata Rainer & $\begin{array}{l}\text { Southern hemisphere: } \\
\text { New Zealand }\end{array}$ & ? & Rainer (1973); Read (1975) \\
\hline natrix (Söderström) & $\begin{array}{l}\text { Southern hemisphere: Chile, } \\
\text { Argentina, South Georgia }\end{array}$ & Viviparous & $\begin{array}{l}\text { Söderström (1920); Hartman } \\
\text { (1948); Hannerz (1956); Blake } \\
\text { (1979) }\end{array}$ \\
\hline otakouica Rainer & $\begin{array}{l}\text { Southern hemisphere: } \\
\text { New Zealand }\end{array}$ & With or without nurse eggs & Rainer (1973); Read (1975) \\
\hline perata (Khlebovitsch) & $\begin{array}{l}\text { Northern hemisphere: Kurile } \\
\text { Islands }\end{array}$ & $?$ & Khlebovitsch (1959) \\
\hline polybranchia (Haswell) & Southern hemisphere: Australia, & With nurse eggs & Read (1975); Blake and \\
\hline $\begin{array}{l}\text { [= euryhalina Hartmann- } \\
\text { Schröder] }\end{array}$ & $\begin{array}{l}\text { New Zealand, South America, } \\
\text { South Africa }\end{array}$ & (New Zealand) & Kudenov (1978) \\
\hline$[=$ wellingtonensis Read $]$ & $\begin{array}{l}\text { Northern hemisphere: } \\
\text { Mediterranean, France, Japan, } \\
\text { British Columbia }\end{array}$ & & \\
\hline proboscidea Hartman & $\begin{array}{l}\text { Northern hemisphere: California } \\
\text { to British Columbia, Japan } \\
\text { Southern hemisphere: Australia }\end{array}$ & $\begin{array}{l}\text { With or without nurse eggs } \\
\text { (California) with nurse eggs } \\
\text { (New Zealand, Australia) }\end{array}$ & $\begin{array}{l}\text { Hartman }(1940 ; 1941) ; \\
\text { Woodwick }\left(1963 a_{i} 1977\right) \\
\text { This study }\end{array}$ \\
\hline pseudonatrix Day & $\begin{array}{l}\text { Southern hemisphere: } \\
\text { South Africa }\end{array}$ & $?$ & $\operatorname{Day}(1961 ; 1967)$ \\
\hline $\begin{array}{l}\text { pugettensis Blake [ = natrix } \\
\text { sensu Berkeley and Berkeley, } \\
\text { not Söderström] }\end{array}$ & $\begin{array}{l}\text { Northern hemisphere: British } \\
\text { Columbia, Washington }\end{array}$ & $?$ & Blake (1979) \\
\hline syrtis Rainer & $\begin{array}{l}\text { Southern hemisphere: } \\
\text { New Zealand }\end{array}$ & Without nurse eggs & Rainer (1973); Read (1975) \\
\hline tricuspa (Hartman) & $\begin{array}{l}\text { Northern hemisphere: California, } \\
\text { Mexico } \\
\text { Southern hemisphere: Chile }\end{array}$ & $\begin{array}{l}\text { Without nurse eggs } \\
\text { (California) }\end{array}$ & $\begin{array}{l}\text { Woodwick (1963b); Blake, } \\
\text { unpubl. }\end{array}$ \\
\hline
\end{tabular}


the larvae spend most or all of their developmental period in the capsules and appear to omit the pelagic phase altogether In a second type of development (Type II), all of the eggs are fertilized, develop to the 5to 6 -setiger stage, leave the capsules and spend 3 or 4 weeks in the plankton. Unlike other reported cases of this type, there is a distinct morphological difference between larval Types I and II. The Type I larvae lack provisional setae during their development, while these setae are present in Type II. Minor differences in pigmentation and general body form are also apparent. Blake (1969) did not find any overlap of developmental Types I and II in populations on the Maine coast (USA). Because provisional setae are so characteristic of spionid larvae, their absence in $P$. quadrilobata Type I is here considered to represent a morphological specialization to a prolonged stay in the egg capsule. The species is probably in the incipient stage of forming two sibling species.

Adelphophagia is common in species of Boccardia. Of the 17 known species, 2 always produce nurse eggs, 5 produce capsules with or without nurse eggs, 4 produce capsules without nurse eggs, 1 is viviparous; for 6 species the reproduction remains unknown (Tabel 1). Hence, 7 of 12 species studied to date have been recorded with nurse eggs at least some of the time. This $58 \%$ compares with $57 \%$ (8 out of 14 species) for the genus Polydora (Blake, 1969; unpubl.), and emphasizes the importance of nurse egg feeding in those spionids of the subfamily Spioninae.

Poecilogony and adelphophagia are more complex in widespread populations of Boccardia proboscidea. In Port Phillip Bay, B. proboscidea produces egg capsules containing nurse eggs and 2 size classes of developing larvae. One of the larval types (Group I) remains small (2-3 setigers) and does not appear to feed on the nurse eggs, while the second type (Group II) becomes quite large (up to 16 setigers) by successfully feeding on the nurse eggs and Group I larvae. If the Group I larvae are released from the capsules artificially, or are able to survive cannibalism by Group II larvae and escape into the plankton, they are capable of feeding on phytoplankton and resume their growth. Group I larvae from a Southern California population have been reared to 10 setigers in laboratory culture (Kudenov, unpubl.). It should be possible, therefore, to derive non-pelagic and short-term planktonic forms from the Group II larvae and long-term planktonic forms from the Group I larvae. All 3 of these possibilities could be derived from a single string of capsules or even from a single capsule. In California, some populations of $B$. proboscidea produce egg capsules having both small and large larvae (Hartman, 1941; Woodwick, 1977) as in the Australian population, while other California populations lack nurse eggs entirely with the larvae becoming pelagic at the 3-4 setiger stage (King, 1976; Blake, unpubl.). Such plasticity in developmental pattern has some advantages relevant to maintenance of populations and dispersal of the species. A non-pelagic development allows emerging juveniles to build up large populations rapidly and to maintain them. Pelagic larvae are dispersed by tides and currents, exposing individuals to new habitats. Once established, non-pelagic larvae produced by these newly settled forms may rapidly establish large populations themselves if conditions are suitable. The presence of long and short-lived pelagic larvae from the brood allows dispersal to nearby and distant localities.

The reason for the inability of Group I larvae to feed on nurse eggs is not clear. One possible reason might be that a slightly slower initial growth rate of the Group I larvae would assure the more precocious Group II larvae of reaching a stage where they could begin feeding on nurse eggs first. Growth is very rapid once nurse egg feeding begins, and it is possible that the much larger Group II larvae actually inhibit feeding by the slower and smaller Group I larvae. Such an inhibition might involve a physical crowding effect, or more likely a specific inhibiting substance emitted by the Group II larvae. An analagous situation has been described for hatching success from egg masses of the Pacific herring Clupea harengus pallasii by Galinka (1971) who suggested that increases in egg mortality may be associated with increasing thickness of egg masses. Developmental abnormalities of head, body form and yolk increase with egg density. It is suggested that hatching of abnormal herring embryos may in part be due to concentration of hatching enzyme in egg masses. The presence of specific enzymes or hormones which might inhibit larval growth are not known for spionid polychaetes, although neurosecretory hormones which delay, inhibit or control gametogenesis are well known for other familes (Olive and Clark, 1978). Large and small larval forms are occasionally observed in egg capsules of Polydora nuchalis (Kudenov, unpubl.), and Rasmussen (1973; his Fig. $30 \mathrm{~B}$ ) depicts an egg capsule of Pygospio elegans having 3 large embryos, a small embryo and no nurse eggs. Rasmussen suggests that the small larva might have a pelagic life before metamorphosis. These observations suggest that similar examples of differential larval growth in capsules may occur in other species of Spionidae.

Works providing information on the reproduction and larval development of Boccardia species are listed in Table 1. Morphologically, the larvae of all species of Boccardia thus far observed are large and fusiform in shape. The larval pigment patterns of $B$. proboscidea, $B$. natrix, B. tricuspa, B. berkeleyorum and B. colum- 
biana include a single medial row of chromatophores. $B$. chilensis is the only species found to lack the medial chromatophores, having instead a very characteristic dark pigmentation to the internal lining of the pharynx, stomach and proctodeum. Small lateral segmental spots occur on the Australian larvae but are lacking on the large planktonic larvae described by Carrasco (1976).

Acknowledgements. We are grateful to the administration of the Marine Studies Group, Ministry for Conservation, State of Victoria (Australia) for providing the facilities and logistical support for this project. The second author was an employee of the Ministry during this study. The first author was supported in part by 2 grants from the National Science Foundation (NSF Grant Int 76-11756 from the US-Australia Cooperative Science Program and NSF Grant GA-30900 from the Oceanography Section). The manuscript benefited especially from comment by N. J. Maciolek, S. Obrebski and K. H. Woodwick.

\section{LITERATURE CITED}

Blake, J. A. (1969). Reproduction and larval development of Polydora from northern New England (Polychaeta: Spionidae). Ophelia 7: 1-63

Blake, J. A. (1979). Revision of some polydorids (Polychaeta: Spionidae) described and recorded from British Columbia by Edith and Cyril Berkeley. Proc Biol. Soc. Wash. 92 (3) $606-617$

Blake, J. A. (1981). Polydora and Boccardia species (Polychaeta: Splonidae) from western Mexico, chiefly from calcareous habitats. Proc. Biol. Soc. Wash. 93: $947-962$

Blake, J. A., Kudenov, J. D. (1978). The Spionidae (Polychaeta) from southeastern Australia and adjacent areas with a revision of the genera. Mem. Nat. Mus. Victoria 39: $171 \quad 280$

Blake, J A., Woodwick, K. H. (1971). A review of the genus Boccardia Carazzi (Polychaeta: Spionidae) with descriptions of two new species. Bull. So. Calif. Acad. Sci. 70: $31-42$

Carrasco, F. D. (1976). Larvas de la familia Spionidae (Polychaeta) en el plancton de la Bahía de Concepcion Chile. Gayana Inst. Biol. Zoologia 38: 1-163

Chia, F. S. (1974). Classification and adaptive signuficance of developmental patterns in marme invertebrates. Thalassia jugosl. 10: 121-130

Clark, R. B. (1977). Reproduction, speciation and polychdete taxonomy. In: Reish, D. J., Fauchald, K. (eds.) Essays on polychaetous annelıds in memory of Dr. Olga Hartman. Allan Hancock Foundation, Untversity of Southern Calıfornia, Los Angeles, pp. 477-501

Day, J. H. (1961). The polychaete faund of South Africa. Part 6 Sedentary species dredged off Cape coasts with a few new records from the shore. J Linn. Sor Lond. 44: 46.3-560

Day, J. H. (1967). A monograph on the Polychata of southern Africa. British Museum of Natural History London. Publ. No. 656 (2 volumes)

Galinka, L. A. (1971). Survival of spawn of the Pacific herring (Clupea harengus pallasii Val.) related to the abundance of the spawning stock. Rapp. P.-v. Réun. Cons, int. Explor Mer 160: 31-33

Giard, A. (1892). Nouvelles remarques sur la poecilogonie. C. r. hebd. Séanc. Acad. Sci. Paris 114: 1549

Giard, A. (1904). La poecilogonie. Int. Congr. Zool. 6: 617-646 Hannerz, L. (1956). Larval development of the polychaete families Spionidae Sars, Disomidae Mesmul and Poecilochuetidae $n$ fam. in the Gullmar Foord (Swe $t^{+} n$ ). Zool. Bidrag. Upps. 31, 1-204

Hartman, O. (1940). Boccardia proboscidea, a new species of spionid worm from Californic. J. Wash. Acad. Sci. 30: $382-387$

Hartman, O. (1941). Some contributions to the biology and life history of Spionidae from California. Allan Hancuck Pacif Exped. 7: 289-324

Hartman, O. (1948). The marıne annelids erected by Kinberg with notes on some other types in the Swedish State Museum. Ark. Zool. 42 A: 1-1.37

Hartman, O. (1961). Ploychaetous annelids from Calıfornı. Allan Hancock Pacif. Exped. 25: 1-226

Hartman, O. (1.969). Atlas of the sedentariate polychaetous annelids from California. Allan Hancock Foundation. University of Southern California, pp. 1-812

Imajima, M., Hartman, O. (1964). The polychaetous annelids of Japan. I-II. Occ. Pap. Allan Hancock Fdn. 26: 1-452

Johnson, R. G. (1970). Variations in diversity within benthic marine communities. Am. Nat. 104: 285-300

Khlebovitsch, $V \vee(1959)$. Speries of polychaete worms from the Kurile Islands which are new or recorded for the first time in the U.S.S.R. (Russ.) Zool. Zh. 28: 167-181

King, K. M. (1976). The life history of Boccardia proboscidea Hartman (Polychaeta: Spionidae). Unpubl. M. A. Thesis, California State University, Long Beach, California

Olive, P. I. W. Clark, R. B. (1978). Physiology of reproduction. In: Mill, P. J. (ed.) Physiology of annelids. Academic Press, New York, pp. 271-368

Rainer, S. (1973). Polydora and related genera (Polychaeta: Spionidae) from Otago waters. J. R. Soc. N.Z. 3: 545-564

Rasmussen, E. (1953). Asexual reproduction in Pygospio elegans Claparede (Polychaeta: Sedentaria). Nature, Lond. 171 (4365): 1161-1162

Rasmussen, E. (1973). Systematics and ecology of the Isefjord marıne fauna (Denmark). Ophelia 11: 1-495

Read, G. B. (1975). Systematics and biology of polydorid species (Polychaeta: Spionidael from Wellington Harbour J. R. Soc. N.Z. 5: 395-419

Simon, J. L. (1967). Reproduction and larval development of Spio setosa. Bull. mar Sci. 17: 398-431

Simon, J. L. (1968). Occurrence of pelagic larvae in Spio setosa Verrill, 1873 Polychaeta: Spionidae. Biol. Bull., mar bıol. Lab., Woods Hole 134: 503-515

Söderstróm, A. (1920). Studien uber die Polychaetenfamile Spionidae. Dissertation, Almqvist and Wicksells, Uppsala

Thorson, G. (1946). Reproduction and larval development of Danish marine bottom invertebrates, with special reference to the planktonic larvae in the Sound (Oresund). Meddr Kommn Danm. Fisk.-og Havunders., Plankton 4 (1): 1-523

Thorson, G. (1950). Reproductive and larval ecology of marine bottom invertebrates. Biol. Rev. 25: 1-45

Woodwick, K. H. (1963a). Comparison of Boccardia columbiana Berkeley and Boccardia proboscidea Hartman (Annelida, Polychaeta). Bull. So. Calif. Acad. Sci. 62: $132-139$

Woodwick, K. H. (1963b). Taxonomic revision of two polydorid species (Annelida, Polychaeta, Spionidae). Proc. Biol. Soc. Wash. 76: 209-216

Woodwick, K. H. (1977). Lecithotrophic larval development in Boccardia proboscidea Hartman. In: Reish, D. J., Fauchald, K. (eds.) Essays on polychaetous annelids in memory of Dr. Olga Hartman. Allan Hancock Foundation, University of Southern California, Los Angeles, pp. $347-371$ 